JAN KLIMEK

Szkoła Główna Handlowa w Warszawie, Polska - Warsaw School of Economics, Poland

Krystyna LesZCZEWSKA

Państwowa Wyższa Szkoła Informatyki i Przedsiębiorczości w Łomży, Polska - Lomza State University of Applied Sciences, Poland

JOANNA SADKOWSKA

Uniwersytet Gdański, Polska - University of Gdansk, Poland

BeATA ŻeLAZKO

Szkoła Główna Handlowa w Warszawie, Warszawa, Polska - Warsaw School of Economics, Poland

\title{
Rola edukacji w kształtowaniu postaw sukcesyjnych studentów kierunków ekonomicznych
}

\section{The Role of Education in Shaping Attitudes towards Succession in the Group of Students of Economic Faculties}

Streszczenie: $\mathrm{W}$ artykule przedstawiono wyniki badań dotyczących intencji sukcesyjnych studentów kierunków ekonomicznych trzech polskich uczelni. Przeanalizowano także problematykę kształtowania edukacji w kontekście stymulowania postaw sukcesyjnych młodych osób rozpoczynających karierę zawodową. Szczególną uwagę zwrócono na możliwości i narzędzia oddziaływania edukacji formalnej na postawy sukcesyjne osób studiujących na kierunkach ekonomicznych. W warstwie teoretycznej artykuł opiera się na wynikach przeglądu literatury naukowej. W części empirycznej wykorzystano metodę badania dokumentów oraz analizę wtórną ilościowych i jakościowych danych zastanych. Przedstawiono wyniki zrealizowanego badania, którym objęto osoby studiujące na kierunkach ekonomicznych w trzech krajowych uczelniach: Szkole Głównej Handlowej w Warszawie, Państwowej Wyższej Szkole Informatyki i Przedsiębiorczości w Łomży oraz Uniwersytecie Gdańskim.

Abstract: The paper presents results of the study dedicated to determining attitudes towards succession among economic faculty students. Its purpose has been determined twofold. First it aims at analysing whether young people are interested in becoming a successor in the companies run by their families, second the paper aims at analysing the possibilities and tools with which formal education can affect attitudes towards succession. The study, in its theoretical part, refers to a number of works dedicated to family businesses and entrepreneurship. Following this, in the empirical part, the results of the research conducted among 142 economic faculty students from Polish family businesses, studying at three Polish universities: Warsaw School of Economics, Lomza State University of Applied Sciences, and University of Gdansk were presented. The findings demonstrate that the interest in succession, compared to other career opportunities, is relatively low. One of the potential determinants might be the programs of education that have been implemented by these particular universities. 
Słowa kluczowe: edukacja; postawy sukcesyjne; przedsiębiorczość; przedsiębiorstwa rodzinne; studenci; sukcesja

Keywords: attitudes toward succession; education, entrepreneurship; family business; students; succession

Otrzymano: 25 października 2019

Received: 25 October 2019

Zaakceptowano: 12 marca 2020

Accepted: 12 March 2020

\section{Sugerowana cytacja/Suggested citation:}

Klimek, J., Leszczewska, K., Sadkowska, J., Żelazko, B. (2020). Rola edukacji w kształtowaniu postaw sukcesyjnych studentów kierunków ekonomicznych. Przedsiębiorczość - Edukacja [Entrepreneurship - Education], 16(1), 106-118. doi: 10.24917/20833296.161.9

\section{Wstęp}

W niniejszym artykule przedmiotem analiz jest kontekst edukacyjny przygotowywania potencjalnych sukcesorów do przejęcia i prowadzenia firmy rodzinnej. Głównym celem artykułu jest próba odpowiedzi na pytanie: Jakie są możliwości oraz sposoby kreowania i wzmacniania zamiaru wyboru ścieżki zawodowej sukcesora przez szkoły wyższe kształcące na kierunkach ekonomicznych?

Z przeglądu krajowej i zagranicznej literatury wynika, że postawy sukcesyjne, będące typem postaw przedsiębiorczych, mogą być kształtowane w ramach edukacji nieformalnej (tj. wychowywania się w rodzinie prowadzącej własny biznes, okazjonalnego bądź ciągłego zdobywania doświadczeń zawodowych w firmie rodzinnej; kontaktów z rówieśnikami/znajomymi, którzy uczestniczą w zarządzaniu taką firmą; udział w spotkaniach/ zjazdach przedsiębiorców reprezentujących biznesy rodzinne) oraz edukacji formalnej przez wybraną ścieżkę studiów, udział w szkoleniach, kursach, warsztatach, korzystanie z doradztwa zawodowego świadczonego przez uczelniane biura karier. Należy jednak podkreślić, że rzeczywisty wpływ tych dwóch form edukacji na postawy sukcesyjne nie został jeszcze rozpoznany. W literaturze można wprawdzie odnaleźć pewne wzmianki o badaniu kontekstu kształtowania postaw sukcesyjnych, jednak wciąż stwierdza się niedostatek wiedzy na ten temat. Luka w wiedzy dotyczy również takich obszarów, jak intencje wyboru kariery sukcesora oraz kształtowanie kompetencji sukcesorów.

Z punktu widzenia zarządzania przedsiębiorstwem rodzinnym, sukcesja, czyli przekazanie władzy i własności firmy w ręce młodszego pokolenia, stanowi wyzwanie o znaczeniu strategicznym. Jego sprawną i skuteczną realizację determinują czynniki dwojakiego rodzaju: wybór i przygotowanie sukcesora/-ów oraz gotowość nestora/ów do rezygnacji z władzy i majątku firmy. Biorąc pod uwagę fakt, że w społeczności polskich przedsiębiorców dominują osoby w wieku emerytalnym i przedemerytalnym, przeprowadzenie sukcesji w zarządzanych przez nich firmach wydaje się problemem pilnym. Jednocześnie coraz więcej szkół wyższych, zwłaszcza tych, które proponują studia na kierunkach ekonomicznych, musi mierzyć się z zadaniem, jakim jest dostosowywanie oferty edukacyjnej do potrzeb gospodarki. Jako jedną z aktywności podejmowanych w tym celu można wskazać wdrażanie oferty sprzyjającej kształtowaniu „sylwetki absolwenta - sukcesora”. Pytanie o to, czy szkoły wyższe w Polsce rzeczywiście prowadzą takie działania, pozostaje nadal bez odpowiedzi. 
W świetle powyższego interesującym obszarem dociekań naukowych jest sfera zaangażowania szkół wyższych w działania edukacyjne, które mogą i powinny wspierać realizację pewnych procesów zachodzących w przedsiębiorstwach rodzinnych. Autorzy niniejszego artykułu podjęli próbę oceny atrakcyjności kariery sukcesora, zbadania skłonności studentów do realizacji wizji własnego rozwoju w warunkach firmy rodzinnej oraz zdiagnozowania zainteresowania sukcesją w grupie osób studiujących na kierunkach ekonomicznych w wybranych trzech szkołach wyższych. Ponadto dokonali zestawienia wyników tego przedsięwzięcia badawczego $\mathrm{z}$ wynikami analizy aktywności wytypowanych szkół w zakresie kształcenia dla przedsiębiorczości rodzinnej (programów studiów oraz usług biura karier). Prezentowany w artykule materiał empiryczny został zebrany w roku 2017 w Szkole Głównej Handlowej w Warszawie, w Państwowej Wyższej Szkole Informatyki i Przedsiębiorczości w Łomży oraz w Uniwersytecie Gdańskim.

\section{Postawy sukcesyjne - istota i znaczenie w biznesie rodzinnym}

Niezależnie od przyjętego sposobu definiowania przedsiębiorstw rodzinnych badacze podkreślają, że charakterystyczną cechą tych podmiotów jest długookresowa perspektywa funkcjonowania i dążenie właścicieli do przekazania firmy rodzinnej następcom (Hall, 1988). Takie strategie działania sprawiają, że firmy rodzinne odgrywają ważną rolę w stabilizowaniu gospodarki (Leszczewska, 2011). Przyjęcie wielopokoleniowej perspektywy prowadzenia działalności przez firmy rodzinne jest czynnikiem wpływającym korzystnie na rozwój przedsiębiorstw rodzinnych (Lewandowska, Andrzejczak, Stradomski, 2017). Prowadzone badania naukowe wskazują, że jednym z podstawowych problemów firm rodzinnych jest transfer międzypokoleniowy. Decyduje on często o przyszłości firmy. Powszechnie przyjmuje się, że międzypokoleniowy transfer nie jest jednorazowym wydarzeniem, ale procesem, który musi być zaplanowany odpowiednio wcześnie, aby mógł zakończyć się sukcesem (Mazzola, Marchisio, Astrachan, 2006). Sukcesja wymaga stawiania na pierwszym miejscu potrzeb przedsiębiorstwa rodzinnego. W zależności od podjętych rozwiązań firma może zachować rodzinny charakter, gdy proces sukcesji zostanie skutecznie przeprowadzony, lub stracić rodzinny charakter, gdy dokona sprzedaży udziałów lub całego przedsiębiorstwa.

Z badań, które prowadzili T.M. Zellweger, F.W. Kellermanns, J.J. Chrisman, J.H. Chua (2012) wynika, że strategia wewnątrzrodzinna jest skorelowana z: siłą więzów i relacji między członkami rodziny, zaangażowaniem rodziny w sprawy firmy, dostępem członków rodziny do finansów przedsiębiorstwa i orientacją prorodzinną. Statystyki gospodarki amerykańskiej pokazują, że szanse na to, że firma rodzinna w drugim pokoleniu pozostanie w rękach rodziny, wynoszą ok. 30\%, a w trzecim pokoleniu - niewiele ponad $10 \%$ (Fleming, 2006). W Polsce obecnie wiele przedsiębiorstw rodzinnych jest na etapie podejmowania kluczowych decyzji związanych z przekazaniem firmy przez założycieli następcom. Pierwsza zmiana generacyjna to przełomowy moment w firmie rodzinnej, gdyż na tym etapie założyciel i jego rodzina powinni ustalić system wartości i formalne regulacje określające sposób sprawowania władzy oraz udziały własnościowe spadkobierców.

Proces sukcesji jest przedmiotem zainteresowania wielu badaczy firm rodzinnych (Aronoff, McClure, Ward, 2012; Jeżak, 2014; Lansberg, Astrachan, 1994; Le Breton-Miller, Miller, Steier, 2004; Lewandowska, 2015; Gersick, Davis, Hampton, Lansberg, 1997; Handler, 1994; Massis, Chua, Chrisman, 2008; Murrey, 2003; Sharma, Chrisman, 
Pablo, Chua, 2001; Safin, Pluta, Pabjan, 2014; Sułkowski, Marjański, 2009; Surdej, Wach, 2010; Więcek-Janka, Hadryś, 2016; Ward, 2004; Zellweger, Kellermanns, Chrisman, Chua, 2012). Badacze, definiując sukcesję, podkreślają, że to dynamiczny proces zachodzący między dwiema generacjami, który ma na celu transfer do młodszego pokolenia własności, władzy, wiedzy i wartości cennych dla firmy rodzinnej. Na przebieg tego procesu wpływają zarówno emocje uczestników, jak i determinanty biznesowe. Czynnikiem mającym wpływ na proces sukcesji jest także kontekst nierodzinny - otoczenie biznesowe przedsiębiorstwa, które tworzy warunki dla funkcjonowania przedsiębiorstw rodzinnych i przeprowadzania sukcesji.

Sukcesja wewnątrzrodzinna jest jedną z wielu możliwości, jednakże badania sugerują, że większość właścicieli firm rodzinnych chciałaby zachować kontrolę rodziny nad przedsiębiorstwem w kolejnych pokoleniach. Harmonijny przebieg sukcesji zależy od równoczesnego wystąpienia dwóch warunków: chęci ustąpienia przez kierującego firmą rodzinną (co jest szczególnie trudne w przypadku założycieli utożsamiających się emocjonalnie z firmą, którą stworzyli) i chęci przejęcia firmy przez wybranego następcę (Surdej, Wach, 2010). Obszarem relatywnie słabo rozpoznanym dotychczas przez badaczy, zwłaszcza jeśli chodzi o Polskę, są postawy sukcesyjne, czyli różne typy poglądów w sprawie sukcesji i powiązane z nimi zachowania jednostek (Klimek, Żelazko, Leszczewska, Sadkowska, 2018). P. Sharma i P.G. Irving przeprowadzili badania, które dostarczają odpowiedzi na pytanie, co sprawia, że dana osoba wyraża chęć zostania sukcesorem (Surdej, Wach, 2010). Wyróżnili oni następujące motywacje potencjalnych spadkobierców:

1. zobowiązanie emocjonalne - przywiązanie uczuciowe, utożsamianie się z firmą rodzinną,

2. zobowiązanie normatywne - przekonanie, że powinno się wypełnić zobowiązania wobec rodziny, stając się spadkobiercą firmy rodzinnej,

3. zobowiązanie oparte na kalkulacji przewidywanych korzyści i kosztów odejścia z firmy rodzinnej (racjonalna ocena korzyści związanych z przyjęciem roli sukcesora i kosztów alternatywnych wynikających z podjęcia takiej decyzji).

Można stwierdzić, że w sukcesji planowanej (a nie przeprowadzanej doraźnie z powodu nagłego odejścia nestora) wykorzystywane są wszystkie typy przedstawionych wyżej zobowiązań.

Ł. Sułkowski, A. Marjański (2009) przedstawili model czynników odpowiadających za powodzenie procesu sukcesji. Badacze podkreślili, że udana sukcesja determinowana jest przede wszystkim postawą sukcesora i nestora. Analizując czynniki związane z nestorem, najczęściej bierze się pod uwagę takie kwestie, jak: cechy osobowości i motywacja nestora, relacje między nestorem a sukcesorem, zdolność nestora do delegowania zadań, nastawienie na współpracę. Nestorzy, inicjując sukcesję, nadają jej kształt, określają horyzont czasowy, wybierają następcę (następców), którym zamierzają przekazać przedsiębiorstwo. Sukcesorzy muszą skonfrontować swoje zamiary przejęcia i prowadzenia przedsiębiorstwa $\mathrm{z}$ oczekiwaniami nestora.

A. Hadryś-Nowak (2019) przedstawiła trzy główne kategorie czynników wpływających na skuteczność procesu sukcesji:

1. przygotowanie sukcesorów, w tym: wykształcenie, praktyka, doświadczenie zawodowe, w szczególności poza przedsiębiorstwem rodzinnym, staż pracy, motywacja do zaangażowania się w firmie rodzinnej, postrzeganie swojego przygotowania do pracy w firmie rodzinnej przez potencjalnych sukcesorów; 
2. relacje między członkami rodziny, w tym: komunikacja, zaufanie, zaangażowanie, lojalność, konflikty, zazdrość, rywalizacja między rodzeństwem, zawirowania rodzinne, wspólne wartości;

3. planowanie sukcesji, w tym: korzystanie z konsultantów/doradców biznesowych, planowanie podatkowe, utworzenie Rady Rodzinnej.

W literaturze przedmiotu przedstawiane są różnorodne modele procesu sukcesji. Modelem szczególnie często powoływanym przez naukowców jest model, który opracowali I. Le Breton-Miller, D. Miller oraz P. Steier (2004). Obejmuje on następujące etapy:

1. ustalanie zasad sukcesji,

2. wychowanie (przygotowanie) sukcesora,

3. przekazanie władzy i własności.

Z uwagi na tematykę artykułu szczególnie ważny jest etap wychowania przyszłego następcy firmy rodzinnej. Z licznych badań wynika, że głównymi czynnikami wpływającymi na udaną sukcesję są: przygotowanie następcy do przejęcia firmy (wykształcenie, doświadczenie zdobyte poza przedsiębiorstwem rodzinnym) i harmonijne relacje między nestorem a sukcesorem (Safin, 2007). Badacze podkreślają, że proces kształtowania postaw sukcesyjnych powinien zaczynać się w dzieciństwie przez dobór odpowiedniej ścieżki edukacyjnej, w tym kierunku studiów, i poznawanie specyfiki przedsiębiorstwa rodzinnego (Brockhaus, 2004; Lansberg, Astrachan, 1994).

Rekomendacje dotyczące kształcenia dzieci przedsiębiorców rodzinnych zaproponowała także Komisja Europejska (European Commission, 2009). Eksperci KE w opracowanym przez siebie raporcie wskazują, że ponieważ większość przedsiębiorstw rozpoczyna działalność jako firmy rodzinne, edukacja powinna obejmować zagadnienia związane z family business, takie jak własność, sukcesja i zarządzanie firmą rodziną, aby lepiej przygotować przyszłych przedsiębiorców do skutecznego prowadzenia firmy. Kształcenia z zakresu zarządzania przedsiębiorstwami rodzinnymi nie powinno ograniczać się do szkół biznesu. Edukacja w zakresie przedsiębiorczości powinna wspierać nowych przedsiębiorców rodzinnych, a także promować zachowania przedsiębiorcze wśród potencjalnych spadkobierców istniejących firm rodzinnych.

\section{Postawy sukcesyjne studentów kierunków ekonomicznych}

W tej części artykułu przedstawiono wyniki przeprowadzonych przez autorów badań empirycznych dotyczących zainteresowania przejęciem zarządzania przedsiębiorstwem, które pozostaje aktualnie w rodzinie badanych osób. Badaniem objęto 142 studentów studiujących na kierunkach ekonomicznych w 3 polskich uczelniach: Szkole Głównej Handlowej w Warszawie, w Państwowej Wyższej Szkole Informatyki i Przedsiębiorczości w Łomży oraz w Uniwersytecie Gdańskim. Do analizy włączono tylko tych studentów, $\mathrm{w}$ których rodzinie $\mathrm{w}$ momencie przeprowadzania badania było prowadzone przedsiębiorstwo spełniające wymogi definicyjne przedsiębiorstwa rodzinnego, takie jak: własność, zarządzanie, kontrola. Syntetyczne wyniki badania przedstawiono poniżej.

Analizując dane przedstawione na rycinie 1, warto wskazać przede wszystkim na relatywnie niskie zainteresowanie sukcesją jako opcją kariery zawodowej (23\%). Szczególnie interesujący jest fakt, iż równocześnie 37\% badanych studentów wyraziło intencję założenia i prowadzenia po ukończeniu studiów własnego przedsiębiorstwa. Jest to ciekawe zjawisko, wziąwszy po uwagę, iż w rodzinach powyższych osób jest już prowadzone 


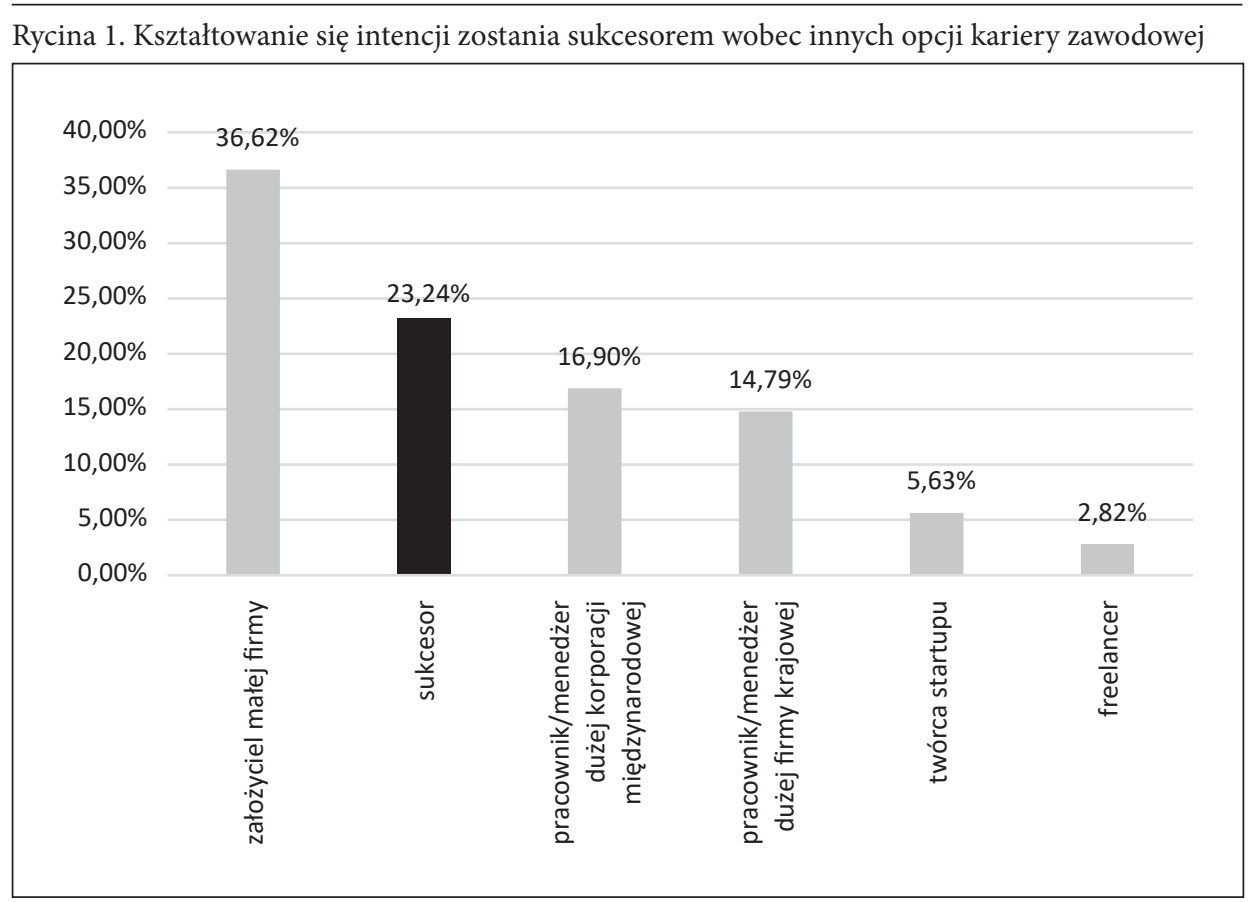

Źródło: Klimek, Żelazko, Leszczewska, Sadkowska (2019: 17)

przedsiębiorstwo, które te osoby mogłyby przejąć w przyszłości. Potencjalnymi przyczynami tej sytuacji mogą być, oprócz braku zainteresowania profilem prowadzonej działalności, zagrożenie konfliktem z nestorem, chęć zdobycia własnego doświadczenia i sprawdzenia się jako założyciel innego podmiotu, by następnie powrócić do przedsiębiorstwa rodzinnego. Taki scenariusz jest często realizowany przez sukcesorów przedsiębiorstw rodzinnych w gospodarkach wysokorozwiniętych.

W celu pogłębienia powyższego wątku badawczego na kolejnym wykresie przedstawiono kształtowanie się zainteresowania sukcesją w podziale na poszczególne badane uczelnie.

Analiza ryciny 2 pozwala zauważyć przede wszystkim istotną dysproporcję w odpowiedziach dotyczących wyboru przez badanych studentów jednej z dwóch opcji kariery zawodowej - jako założyciela małego przedsiębiorstwa oraz zatrudnienia się w dużej korporacji zagranicznej. Dysproporcja ta została zidentyfikowana pomiędzy studentami Szkoły Głównej Handlowej a studentami Uniwersytetu Gdańskiego oraz Państwowej Wyższej Szkoły Informatyki i Przedsiębiorczości w Łomży. Badani studenci reprezentujący Szkołę Główną Handlową tworzyli grupę, która wykazywała najmniejsze zainteresowanie założeniem własnego przedsiębiorstwa w przyszłości. Równocześnie jako najbardziej interesującą opcję zawodową wskazywali oni zatrudnienie w dużej korporacji. Natomiast rozkład odpowiedzi dla badanych osób z dwóch pozostałych szkół wyższych był zbliżony. Studenci Szkoły Głównej Handlowej wykazywali również największe zainteresowanie założeniem startupu. Nie byli oni natomiast zainteresowani zatrudnieniem w dużym, krajowym przedsiębiorstwie. Zidentyfikowaną sytuację należy uznać za interesującą poznawczo. Jednym z jej kluczowych uwarunkowań może być profil kształcenia w badanych uczelniach. PWSIiP w Łomży jest uczelnią zawodową, o praktycznym profilu 
Rycina 2. Wybór ścieżki zawodowej sukcesora, \%

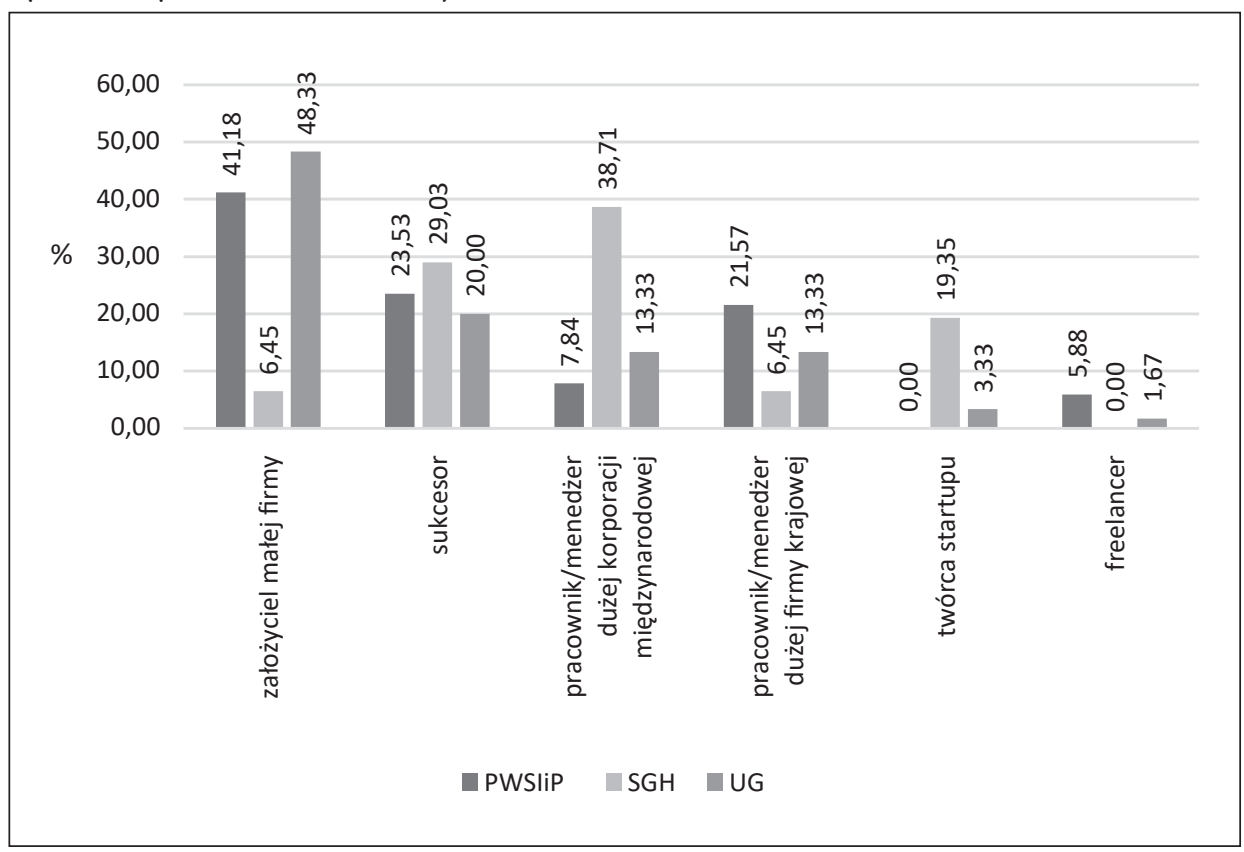

Źródło: opracowanie własne na podstawie przeprowadzonych badań

kształcenia, który powoduje, że studenci mają intensywny kontakt z praktyką gospodarczą. W kolejnej części artykułu przeanalizowano programy kształcenia badanych szkół wyższych jako jedno z potencjalnych uwarunkowań zidentyfikowanych rozbieżności.

\section{Edukacja dla przedsiębiorczości rodzinnej w badanych szkołach wyższych}

$\mathrm{Z}$ analizy literatury wynika, że postawę sukcesyjną studenta konstytuują następujące elementy: atrakcyjność kariery sukcesora, skłonność do działania w ramach firmy rodzinnej (określana na podstawie deklaracji dotyczącej zaangażowania w działalność firmy rodzinnej), chęć wykonania działania (określana na podstawie deklarowanej chęci udziału w zarządzaniu firmą rodzinną w przyszłości) oraz zainteresowanie sukcesją (Klimek, Żelazko, Leszczewska, Sadkowska, 2018). Edukacja formalna w zakresie przedsiębiorczości, a zwłaszcza przedsiębiorczości rodzinnej, której istotą jest przekazywanie wiedzy i rozwijanie umiejętności, potencjalnie wpływa na: proces tworzenia w świadomości studenta wizerunku firmy rodzinnej jako miejsca realizacji ścieżki kariery zawodowej, zainteresowanie aktywnością w ramach biznesu rodzinnego oraz zainteresowanie sferą zarządzania w przedsiębiorstwie należącym do rodziny. Dzięki odpowiednio dobranej ofercie dydaktycznej ukierunkowanej na rozwój kompetencji przedsiębiorczych, tworzeniu infrastruktury i świadczeniu dodatkowych usług, a także organizowaniu wydarzeń upowszechniających wiedzę o biznesie rodzinnym i sukcesji szkoła wyższa może w sposób bezpośredni oddziaływać na postawy sukcesyjne osób podejmujących naukę na prowadzonych przez nią kierunkach studiów ekonomicznych. Pośredni wpływ na postawy sukcesyjne wywierają natomiast czynniki związane ze sferą zarządzania uczelnią, takie jak: przywiązanie 
uczelni do tradycji, system wartości, relacje z interesariuszami, innowacyjność w sferze kształcenia, strategiczne obszary aktywności edukacyjnej, wdrażana strategia, ranga szkoły w lokalnym i regionalnym otoczeniu. Wyszczególnienie obszarów określających zaangażowanie szkół wyższych w edukację dla przedsiębiorczości rodzinnej przedstawiono na rycinie 3 .

Rycina 3. Obszary zaangażowania szkół wyższych w edukację dla przedsiębiorczości rodzinnej

\begin{tabular}{|l|}
\hline \multicolumn{1}{|c|}{$\begin{array}{c}\text { Kluczowe obszary określające zaangażowanie szkół wyższych } \\
\text { w edukację dla przedsiębiorczości rodzinnej }\end{array}$} \\
\hline 1. Misja, wizja i strategia uczelni \\
\hline 2. Oferta kierunków i specjalności \\
\hline 3. Oferta przedmiotów kierunkowych i specjalizacyjnych \\
\hline 4. Miejsca praktyk i staży dla studentów \\
\hline 5. Dodatkowe formy aktywności edukacyjne proponowane przez szkołę wyższą \\
\hline
\end{tabular}

Źródło: opracowanie własne

Pierwsza z uczelni objętych badaniem, Państwowa Wyższa Szkoła Informatyki i Przedsiębiorczości w Łomży, prowadziła studia zawodowe licencjackie na wielu kierunkach, przy czym w dziedzinach ekonomicznych były to studia na kierunku zarządzanie, w specjalnościach: zarządzanie MŚP; zarządzanie projektami; rachunkowość w zarządzaniu, zarządzanie logistyką w przedsiębiorstwie. Program wskazanych studiów ukierunkowany był na edukację stymulującą przedsiębiorczość lokalną i regionalną. Misją uczelni jest kształcenie praktyków, toteż program studiów był formułowany z uwzględnieniem opinii przedstawicieli regionalnego i lokalnego rynku pracy. Jako wiodący profil absolwenta studiów na tym kierunku uczelnia wskazywała „ambitnego przedsiębiorcę potrafiącego wykorzystywać fundusze unijne”. Przedsiębiorczość - zgodnie z programem studiów stanowiła przedmiot kierunkowy szczegółowy. W ofercie dydaktycznej nie stwierdzono przedmiotów, które dotyczyłyby zarządzania przedsiębiorstwem rodzinnym lub sukcesji w przedsiębiorstwach. Studenci i absolwenci uczelni mogli skorzystać z usług oferowanych przez Inkubator Ludzi Biznesu - tj. możliwości przetestowania pomysłu na biznes oraz podjęcia aktywności gospodarczej pod parasolem inkubatora (bez konieczności rejestracji własnej firmy). Uczelniane biuro karier współpracowało z polskimi, małymi i średnimi przedsiębiorstwami w regionie w celu zapewnienia swoim studentom możliwości odbycia praktyki i przygotowania do prowadzenia własnego biznesu.

Szkoła Główna Handlowa w Warszawie kształci na trzech poziomach: licencjackim, magisterskim oraz doktoranckim. Na poziomie studiów licencjackich - w czasie realizacji badania - oferowane były kierunki: ekonomia; finanse i rachunkowość; globalny biznes, finanse i zarządzanie (Governance); metody ilościowe w ekonomii i systemy informacyjne; międzynarodowe stosunki gospodarcze oraz zarządzanie. Na poziomie studiów magisterskich w szkole studiować można było na kierunkach: analiza danych - big data; e-biznes, ekonomia; ekonomiczna analiza prawa; finanse i rachunkowość; globalny biznes, finanse i zarządzanie (Governance); kierunek menedżerski; metody ilościowe w ekonomii i systemy informacyjne; międzynarodowe stosunki gospodarcze; polityka publiczna; turystyka międzynarodowa, hotelarstwo i usługi czasu wolnego; zarządzanie; zarządzanie finansami przedsiębiorstwa. W ofercie dydaktycznej szkoły znajdowały się przedmioty: przedsiębiorczość; trening przedsiębiorczości; podstawy przedsiębiorczości 
technologicznej; przedsiębiorczość - perspektywa startupu; inkubator przedsiębiorczości; przedsiębiorczość międzynarodowa; przedsiębiorczość i etyka w działalności zawodowej i pozazawodowej. W przypadku kierunku zarządzanie przedmioty te należały do przedmiotów związanych z kierunkiem lub specjalnościowych. Ponadto wśród przedmiotów swobodnego wyboru znajdował się przedmiot zarządzanie firmą rodzinną. W promowanie przedsiębiorczości rodzinnej wśród studentów SGH - poprzez organizację wykładów otwartych oraz Dnia Przedsiębiorczości Rodzinnej - angażował się Zakład Przedsiębiorstwa Rodzinnego w Instytucie Przedsiębiorstwa. W ramach uczelni funkcjonował Akademicki Inkubator Przedsiębiorczości oraz Inkubator Startupów. Do Klubu Partnerów SGH należały głównie duże firmy oparte na kapitale zagranicznym (zaliczane do grupy korporacji międzynarodowych). Tego typu firmy podejmowały też współpracę z Biurem Kariery SGH - jako oferenci praktyk i staży. W 2017 r. uczelniane Centrum Przedsiębiorczości i Transferu Technologii zainicjowało Startup Hub, przedsięwzięcie mające na celu tworzenie warunków do uruchamiania innowacyjnych projektów biznesowych w obszarze wysokich technologii. Misją SGH było kształcenie specjalistów w dziedzinie ekonomii i zarządzania, przygotowanych do pracy zarówno w krajowych, jak i w zagranicznych instytucjach i przedsiębiorstwach.

Uniwersytet Gdański, podobnie jak Państwowa Wyższa Szkoła Informatyki i Przedsiębiorczości, oferuje różne kierunki studiów. Na Wydziale Zarządzania, na studiach licencjackich i magisterskich, studenci mieli możliwość podjęcia studiów ekonomicznych na kierunkach: finanse i rachunkowość; informatyka i ekonometria; podatki i doradztwo podatkowe; ubezpieczenia - studia interdyscyplinarne; zarządzanie. W ramach tych kierunków uczelnia proponowała szereg specjalności związanych z funkcjonowaniem przedsiębiorstwa, w tym m.in.: inwestycje i nieruchomości; marketing; menedżer; zarządzanie organizacjami; zarządzanie rozwojem przedsiębiorstwa. Studenci tego wydziału mogli korzystać z usług Inkubatora Przedsiębiorczości i Inkubatora Innowacyjności. $\mathrm{W}$ ofercie przedmiotów kierunkowych oraz swobodnego wyboru nie zostały uwzględnione natomiast przedmioty związane z przedsiębiorczością rodzinną. Jeśli chodzi o profil absolwenta, Uniwersytet Gdański promował profil specjalisty dysponującego wiedzą i umiejętnościami, które spełniają oczekiwania sfer gospodarczych i społecznych (zwłaszcza europejskiego rynku pracy). Aspektem podkreślanym w strategii rozwoju uczelni było podejmowanie działań ukierunkowanych na dostosowywanie oferty dydaktycznej do zainteresowań młodzieży chcącej podjąć kształcenie w tej jednostce.

\section{Zakończenie}

Znaczenie przedsiębiorstw rodzinnych w każdej gospodarce pozostaje niepodważalne. Jest to związane m.in. $\mathrm{z}$ wielkością wytwarzanego produktu krajowego brutto (PKB), popytem na pracowników, który jest generowany przez podmioty rodzinne, a także $\mathrm{z}$ wdrażaniem nowych rozwiązań. Przedsiębiorstwa rodzinne napotykają jednak w prowadzonej działalności na liczne ograniczenia, których część wynika z faktu, iż są to przede wszystkim podmioty mikro, małe i średnie. Równocześnie jednak podmioty te są konfrontowane $\mathrm{z}$ wymaganiami dotyczącymi wnoszenia przez nie wkładu w zwiększanie innowacyjności gospodarki. Jest to wyzwanie szczególnie trudne, biorąc pod uwagę możliwości badanych podmiotów dotyczące ponoszenia nakładów na prace badawczo-rozwojowe (por. Sadkowska, 2015), sygnalizowane przez nie problemy sukcesyjne oraz problemy 
w sferze pozyskiwania zasobów pracy. Biorąc pod uwagę powyższe uwarunkowania, priorytetem staje się poszukiwanie rozwiązań umożliwiających pokonanie wspomnianych ograniczeń w rozwoju przedsiębiorstw rodzinnych. Warto jednak wskazać, iż nadal nierozstrzygnięte są ważne pytania badawcze dotyczące postaw sukcesyjnych młodych osób, które w przyszłości mogłyby zostać sukcesorami firm rodzinnych, a tym samym, korzystając ze zdobytego wykształcenia, stymulować wzrost innowacyjności tej grupy przedsiębiorstw. W świetle wyników przeprowadzonych badań empirycznych autorzy wskazują, iż zarówno w sferze badań, jak i w sferze praktyki gospodarczej kluczowe znaczenie ma poszukiwanie przyczyn, które determinują zaistniałą sytuację i powodują relatywnie niskie zainteresowanie rolą sukcesora wśród badanych osób.

Przy analizowaniu wyników przeprowadzonych badań warto zwrócić uwagę na konieczność zwiększenia zaangażowania badanych szkół wyższych w budowanie oferty dydaktycznej sprzyjającej kreowaniu i wzmacnianiu postaw sukcesyjnych - zwłaszcza w odniesieniu do PWSIiP oraz UG. W świetle dotychczasowych rozważań należy uznać, że przez tworzenie oferty dydaktycznej i świadczenie dodatkowych usług, przykładowo takich jak inkubacja i doradztwo, można stymulować zainteresowanie karierą sukcesora i tym samym umacniać postawy sukcesyjne studentów kierunków ekonomicznych.

W Polsce brak jest wyraźnego ukierunkowania oferty edukacyjnej oraz projektów dydaktycznych i doradczych na potrzeby sektora family business. Przyczyną tego stanu może być z jednej strony niska świadomość oczekiwań i problemów firm rodzinnych, $\mathrm{z}$ drugiej strony - słabe zaangażowanie przedsiębiorstw rodzinnych w budowanie relacji ze szkołami wyższymi. Wzrost aktywności przedsiębiorstw rodzinnych jako interesariuszy szkół wyższych mógłby znacząco wpłynąć na zwiększenie roli edukacji formalnej prowadzonej przez szkoły wyższe w kształtowaniu zainteresowania studentów ścieżką kariery sukcesora.

Literatura

References

Apanowicz, J. (2002). Metodologia ogólna. Gdynia: Wydawnictwo Diecezji Pelplińskiej Bernardinum.

Aronoff, C.E., McClure, C.L., Ward, J.L. (2012). Sukcesja w firmach rodzinnych. Ostateczny test wielkości. Kraków: Wydawnictwo MiP.

Brockhaus, R.H. (2004). Family Business Succession: Suggestions for Future Research. Family Business Review, 17(2), 165-177.

European Commission (2009). Final Report of the Expert Group. Overview of Family-Business-Relevant Issues: Research, Networks, Policy Measures and Exiting Studies.

Fleming, Q.J. (2006). Tajniki przetrwania firmy rodzinnej. Gliwice: Helion.

Gersick, K.E., Davis, J.A., Hampton, M., Lansberg, I. (1997). Generation to Generation. Life cycles of the Family Business. Boston: Harvard Business School Press.

Hadryś-Nowak, A., (2019), Międzynarodowe przedsiębiorstwo rodzinne. Znaczenie orientacji przedsiębiorczej sukcesora dla internacjonalizacji przedsiębiorstwa rodzinnego. Warszawa: CeDeWu.

Hall, P.D. (1988). A Historical Overview of Family Firms in the United States. Family Business Review, $1,51-68$.

Handler, W.C. (1994). Succession in Family Business: A Review of the Research. Family Business Review, $7(2), 133-157$.

Jeżak, J. (red.). (2014). Przedsiębiorstwa rodzinne w Polsce. Znaczenie ekonomiczne oraz strategiczne problemy rozwoju. Łódź: Wyd. Uniwersytetu Łódzkiego. 
Klimek, J., Żelazko, B., Leszczewska, K., Sadkowska, J. (2018). Postawy sukcesyjne studentów kierunków ekonomicznych - aspekt teoretyczny i wyniki badania pilotażowego. Przedsiębiorczość i Zarzadzanie, $X I X(7 / 1), 41-56$.

Klimek, J., Leszczewska, K., Żelazko, B., Sadkowska, J. (2019). Kluczowe determinanty postaw sukcesyjnych studentów kierunków ekonomicznych. Studia i Monografie. Społeczna Akademia Nauk, 92, 9-24.

Lansberg, L., Astrachan, J.H. (1994). Influence of Family Relationships on Succession Planning and Training: The Importance of Mediating Factors. Family Business Review, 7(1), 39-59.

Le Breton-Miller, I., Miller, D., Steier, P. (2004). Toward an Integrative Model of Effective FOB Succession. Entrepreneurship Theory and Practice, 28(4).

Leszczewska, K. (2011). Funkcjonowanie firm rodzinnych w warunkach kryzysu. Ekonomika i Organizacja Przedsiębiorstwa, 1(732), 65-72.

Lewandowska, A. (2015). Kody wartości. Czyli jak efektywnie przejść przez sukcesję w firmie rodzinnej. Poznań: Lewandowska i Partnerzy.

Lewandowska, A., Andrzejczak, P., Stradomski, M. (red.) (2017). Narodziny firmy rodzinnej. Jak mądrze zaplanować sukcesję i przekazać biznes następcom. Poznań: Instytut Biznesu Rodzinnego.

Massis, A.D., Chua, J.H., Chrisman, J.J. (2008). Factors Preventing Intra-Family Succession. Family Business Review, 21(2), 183-199.

Mazzola, P., Marchisio, G., Astrachan, J. (2006). Using the strategic planning process as a next-generation training tool in family business. In: Z.P. Poutziouris, Kosmas, X.S., Rau, S.B., Handbook of Research on Family Business. UK: Edward Elgar, 402-421.

Murrey, B. (2003). The Succession Transition Process: a Longitudinal Perspective. Family Business Review, 16(1), 17-33.

Sadkowska, J. (2015). Aktywność badawczo-rozwojowa jako determinanta wzrostu innowacyjnego firm rodzinnych. Przedsiębiorczość i Zarzadzanie, XVI(7/II), 155-168.

Safin, K., Pluta, J., Pabjan, B. (2014). Strategie sukcesyjne polskich przedsiębiorstw rodzinnych. Warszawa: Difin.

Sharma, P., Chrisman, J.J., Pablo, A.L., Chua, J.H. (2001). Determinants of Initial Satisfaction with the Succession Process in Family Firms: A Conceptual Model. Entrepreneurship Theory and Practice, 25(3), 17-36.

Sułkowski, Ł., Marjański, A. (2009). Firmy rodzinne. Jak odnieść sukces w sztafecie pokoleń. Warszawa: Poltext.

Surdej, A., Wach, K. (2010). Przedsiębiorstwa rodzinne wobec wyzwań sukcesji. Warszawa: Difin.

Ward, J.L. (2004). Perpetuating the Family Business. New York: Palgrave Macmillan.

Więcek-Janka, E., Hadryś, A. (2016). Kompetencje sukcesorskie - profil wstępny. Przedsiębiorczość i Zarządzanie, XVII(6/III), 61-73.

Zellweger, T.M., Kellermanns, F.W., Chrisman, J.J., Chua, J.H. (2012). Family Control and Family Firm Valuation by Family CEOs: The Importance of Intentions for Transgenerational Control. Organization Science, 23(3), 1-18.

Jan Klimek, dr hab., prof. SGH, Szkoła Główna Handlowa w Warszawie, Kolegium Nauk o Przedsiębiorstwie, Instytut Przedsiębiorstwa, Zakład Przedsiębiorstwa Rodzinnego. Autor licznych publikacji dotyczących rozwoju przedsiębiorczości, doskonalenia zarządzania w sektorze MŚP oraz społecznej odpowiedzialności biznesu. Interesuje się funkcjonowaniem organizacji gospodarczych oraz nowoczesnymi metodami zarządzania tymi organizacjami. Aktywny doradca przedsiębiorstw zarówno na rynku krajowym, jak i zagranicznym. Współtwórca i kierownik polsko-szwajcarskiego projektu wspierania przedsiębiorczości w Polsce. Autor i sprawozdawca opinii Europejskiego Komitetu Ekonomiczno-Społecznego w sprawie przedsiębiorstw rodzinnych w Europie jako źródła ponownego wzrostu gospodarczego i lepszych miejsc pracy. W ramach aktywności dydaktycznej prowadzi zajęcia z przedsiębiorczości, zarządzania sobą oraz etyki biznesu. 
Jan Klimek, associate professor, Warsaw School of Economics, Collegium of Business Administration, Institute of Enterprise, Family Business Unit. He is an author of numerous publications on entrepreneurship development, improvement of management in the SME sector and corporate social responsibility. He is interested in the functioning of business organisations and modern management methods used in them. An active consultant of enterprises both on the domestic and foreign market, co-founder and head of the Polish-Swiss project for supporting entrepreneurship in Poland. He is also an author and rapporteur of the opinion of the European Economic and Social Committee on "Family Business in Europe as Source of Renewed Growth and Better Jobs". He gives lectures on entrepreneurship, self-management and business ethics.

ORCID: https://orcid.org/0000-0003-0986-3147

\author{
Adres/Address: \\ Szkoła Główna Handlowa w Warszawie \\ Kolegium Nauk o Przedsiębiorstwie \\ Instytut Przedsiębiorstwa \\ Zakład Przedsiębiorstwa Rodzinnego \\ ul. Madalińskiego 6/8 pok. 104 \\ 02-513 Warszawa, Polska \\ e-mail: jklime1@sgh.waw.pl
}

Krystyna Leszczewska, dr hab., prof. PWSIiP, Państwowa Wyższa Szkoła Informatyki i Przedsiębiorczości w Łomży, Wydział Nauk Społecznych i Humanistycznych. Jej zainteresowania badawcze koncentrują się wokół przedsiębiorczości rodzinnej (w szczególności modeli biznesu przedsiębiorstw rodzinnych) i kształtowania postaw przedsiębiorczych studentów. Autorka licznych publikacji naukowych z tego zakresu, nauczyciel akademicki, prowadzi zajęcia z przedsiębiorczości, zarządzania, aktywnie współpracuje $\mathrm{z}$ instytucjami otoczenia biznesu i samorządem w zakresie wspierania przedsiębiorczości.

Krystyna Leszczewska, associate professor, Lomza State University of Applied Sciences, The Faculty of Social Sciences and Humanities. The author's research interests focus on family entrepreneurship (in particular business models of family enterprises) and shaping student entrepreneurial attitudes. An author of numerous publications in this field, an academic teacher, she conducts entrepreneurship and management classes, actively cooperates with business environment institutions and local government in supporting entrepreneurship.

ORCID: https://orcid.org/0000-0001-7302-647X

\title{
Adres/Address:
}

Państwowa Wyższa Szkoła Informatyki i Przedsiębiorczości w Łomży

Wydział Nauk Społecznych i Humanistycznych

Zakład Zarządzania

ul. Akademicka 14

18-400 Łomża, Polska

e-mail: kleszczewska@pwsip.edu.pl

Joanna Sadkowska, dr, Uniwersytet Gdański, autorka licznych publikacji poświęconych problematyce przedsiębiorstw rodzinnych ze szczególnym uwzględnieniem zarządzania projektami oraz budowania relacji z interesariuszami przez te podmioty. Prowadziła wykłady oraz badania w Aalborg University, Universidad Europea Miquel de Cervantes w Valladolid, VERN Zagreb, Academia de Studii Economice din Bucuresti. Członek komitetów redakcyjnych czasopism oraz rad naukowych konferencji w kraju i za granicą. Obecnie prowadzi badania w obszarach: zarządzanie projektami przez przedsiębiorstwa rodzinne oraz aspekty kulturowe związane $\mathrm{z}$ budowaniem relacji z interesariuszami przez te podmioty. 
Joanna Sadkowska, PhD, researcher at Business Economics Department at the University of Gdansk. Author of a number of publications dedicated to family businesses, project management. Currently she conducts research in the following fields: project management in family-owned enterprises, cultural aspects of building relationships with stakeholders by family businesses. Lecturer in Project Management and PM modern tools. She has given lectures and run research at: Aalborg University, VERN Zagreb, Academia de Studii Economice din Bucuresti, Universidad Europea Miquel de Cervantes Valladolid.

ORCID: https://orcid.org/0000-0002-6275-7071

\author{
Adres/Address: \\ Uniwersytet Gdański \\ Wydział Zarządzania \\ Katedra Ekonomiki Przedsiębiorstw \\ Zakład Ekonomiki Małej Firmy \\ ul. Armii Krajowej 101 \\ 81-824 Sopot, Polska \\ e-mail: joanna.sadkowska@ug.edu.pl
}

Beata Żelazko, dr, Szkoła Główna Handlowa w Warszawie, Kolegium Nauk o Przedsiębiorstwie, Instytut Przedsiębiorstwa, Zakład Przedsiębiorstwa Rodzinnego. Autorka jest zaangażowana w promocję idei przedsiębiorczości (zwłaszcza rodzinnej, technologicznej i stylu życia), budowanie relacji sektora nauki z biznesem oraz działalność konsultingową. Pomysłodawczyni i współorganizatorka wydarzenia „Dzień Przedsiębiorczości Rodzinnej w SGH”. Obecnie prowadzi badania w następujących obszarach: wspieranie rozwoju przedsiębiorstw, kreowanie postaw sukcesyjnych, zarządzanie innowacjami w przedsiębiorstwie. W działalności dydaktycznej zajmuje się przekazywaniem wiedzy o funkcjonowaniu współczesnych przedsiębiorstw, formułowaniu i wdrażaniu strategii konkurencji i rozwoju oraz wprowadzaniu zmian w życiu osobistym i zawodowym.

Beata Żelazko, PhD, Warsaw School of Economics, Collegium of Business Administration, Institute of Enterprise, Family Business Unit, engaged in promoting the idea of entrepreneurship (especially family, technology and lifestyle), building relations between the science and business sectors and consulting activities. Originator and co-organiser of the event "Family Entrepreneurial Day at the Warsaw School of Economics". Currently, she conducts research in the following areas: supporting the development of enterprises, creating attitudes toward succession, managing innovations in the enterprise. In didactic activity, she deals with the transfer of knowledge on the functioning of contemporary enterprises, formulation and implementation of competition and development strategies and the management of changes in personal and professional life.

ORCID: https://orcid.org/0000-0002-8086-8015

\author{
Adres/Address: \\ Szkoła Główna Handlowa w Warszawie \\ Kolegium Nauk o Przedsiębiorstwie \\ Instytut Przedsiębiorstwa \\ Zakład Przedsiębiorstwa Rodzinnego \\ ul. Madalińskiego 6/8 pok. 117 \\ 02-513 Warszawa, Polska \\ e-mail: beata.zelazko@sgh.waw.pl
}

